\title{
Teodors Hermanovskis, Art Deco and a Provincial Town Ogre
}

\author{
Renāte Čaupale, Riga Technical University
}

\begin{abstract}
The architecture of mansions was an integral part of popularisation of modern trends in the interwar period in Latvia. One of the greatest masters in this area was a building engineer Teodors Hermanovskis. Ogre - a provincial small town near Riga had become popular among the Riga intelligentsia as a recreation place and a summer residence site. It offered a new environment, a challenge for architects to implement modern ideas in mansion and summer cottage projects over a relatively short period of time. It was a time when the functionalism that was topical in Europe also allowed the presence of Art Deco in projects, which was organically logical. The mansions designed by Teodors Hermanovskis in Ogre are indicative of an architect who fulfils modern and daring ideas in interwar Latvia, as the one whose projects can be classified as belonging to Art Deco style.
\end{abstract}

KEYWORDS: architectural history, Art Deco mansion, Functionalist mansion, the 1920s and 1930s.

In the 1920s and 1930s, architecture in the new state of Latvia saw certain activities that were generally characteristic of that time period in Europe. Contrary to the pronouncements of some opponents in press, the ideas of Modern Movement or Functionalism, which found their beginning in Deutsche Werkbund and Bauhaus, were playing an important role, thus proposing a completely new way of architectural thinking for Europe - moving to architecture of simple geometric forms.

Not only large cities of Latvia were open for the modern tendencies; also provincial towns and the numerous emerging cultural centres were drawn into the political and economic change. Ogre, although it had but recently obtained town status (in 1928), was actively developing as a place of culture and recreation near Riga. Regular train traffic was an important factor in ensuring a close link with the capital. Many representatives of

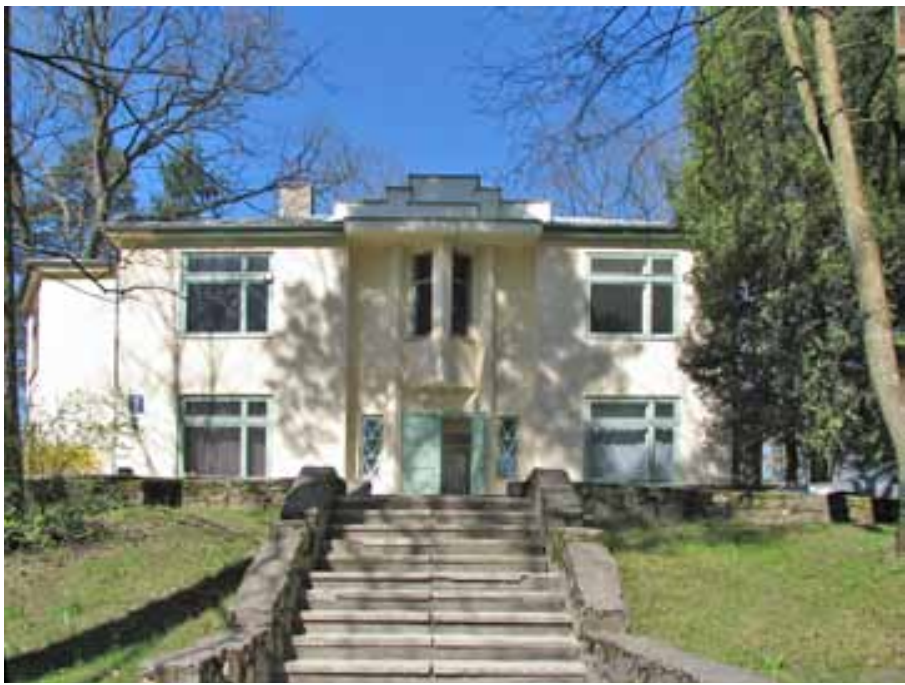

Fig. 1. Mansion at Kalna prospekts 3, Ogre. 1927. Teodors Hermanovskis. [7]
Riga intelligentsia chose the small and quiet town on the River Ogre as their seasonal dwelling place. The town offered a new environment, a challenge for architects to implement modern ideas in projects of private houses and summer cottages within a relatively short period of time, sometimes also with the limited choice of materials and modest financial possibilities. It was a time when Functionalism that was topical in Europe also allowed the presence of Art Deco in projects, which was organic and logical.

An important role in the development of Latvian architecture in the interwar period was played by Teodors Hermanovskis, a building engineer by education. Being a great master of applying the Modern Movement or Modern Functionalism in the architecture of Riga apartment houses and public buildings, he also produced many mansions, which are still in place not only in the "provincial" Riga left-bank area - Pārdaugava - and other residential districts of Riga characterised by low-rise buildings and abundant greenery, but also the small town of Ogre. In Ogre, which was then a suburban resort near Riga, Hermanovskis built a number of villas, the designs of which not only kept pace with the dynamic compositions of construction shapes found in the capital but sometimes even surpassed them. Hermanovskis' most adventurous Art Deco project is still to be found in Ogre at Kalna prospekts (Avenue) 3 (Figure 1).

Surrounded by pine trees on the outskirts of the town, a picturesque hill mansion was built for the family of Anna Ozolina and the Riga bank manager Pauls Ozolinšs. The house is attractive thanks to its dynamic façade developed in contrasting colours. It is here, in the 1927 project, that, similarly as in the Riga project at Mazā Nometnuu iela (Street) 6 (1927) and even earlier, at Marijas iela 8 (1926), getting ahead of the canonical Paris example the residential/utility building at 118 Avenue des ChampsÉlysées, "Le Normandy" (1929, designed by Jean Desbouis), Teodors Hermanovskis designed triangular oriel windows, an overtly Art Deco detail, which is the main and highly dynamic accent in the composition of the façade (Figure 2). Triangularshaped structures as a decorative element characteristic of the Art Deco era can be found throughout Europe, in more or less outspoken form. For example, the extensive overview of recent British architecture in the Architectural Review of 1928 included photos and plans of typical homes of that time, among them terrace houses in the Silver End Garden Village (Essex) designed by the architect Thomas S. Tait. Houses of Tait's design traditionally had flat roofs, which in the Essex village were painted emerald green, also using this colour for some of the façade details, thus receiving rather negative reactions from the contemporary English society. These buildings, which were typically simple and were, to some extent, regarded as dull, were brightened up only by a few details - Art Deco details - geometrical motifs 


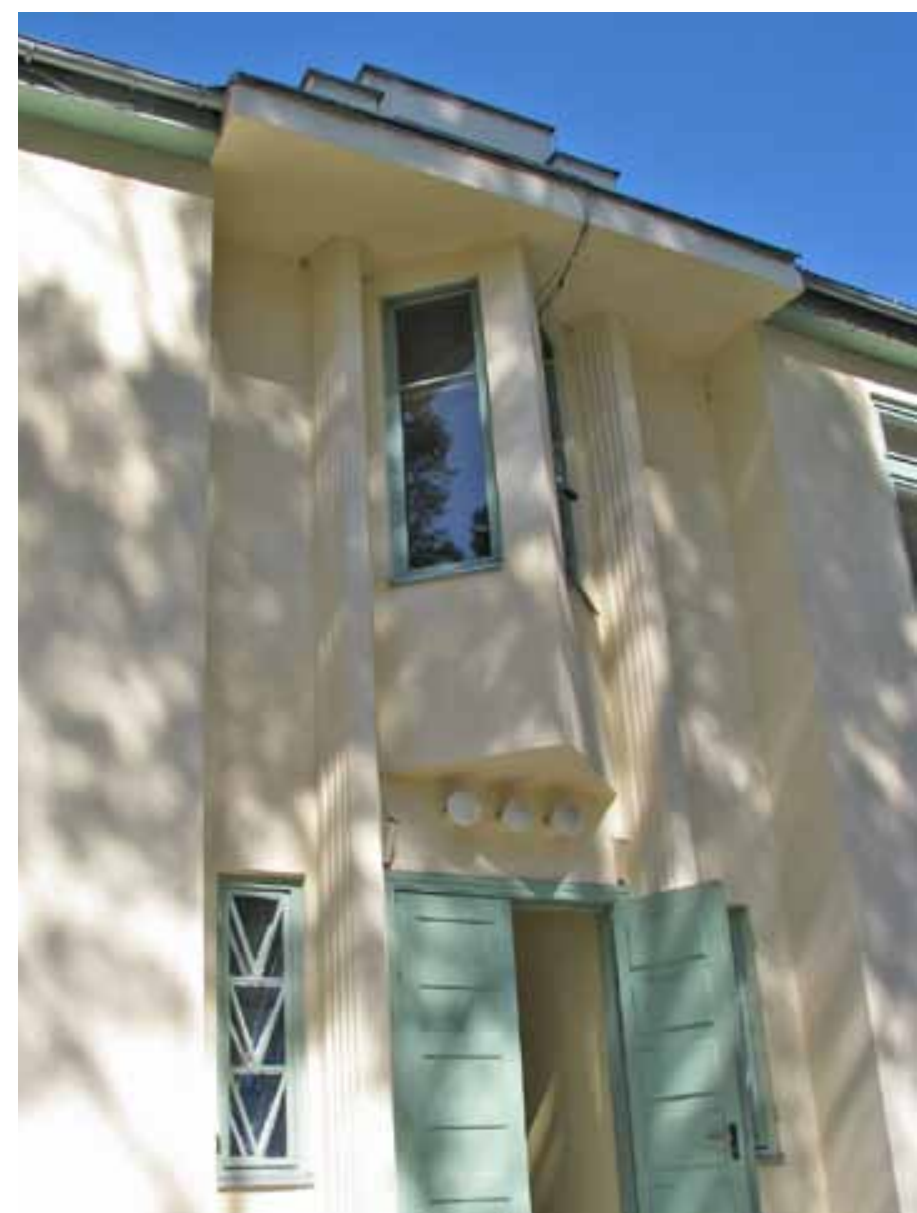

Fig. 2. Façade fragment. Mansion at Kalna prospekts 3, Ogre. 1927. Teodors Hermanovskis. [7]

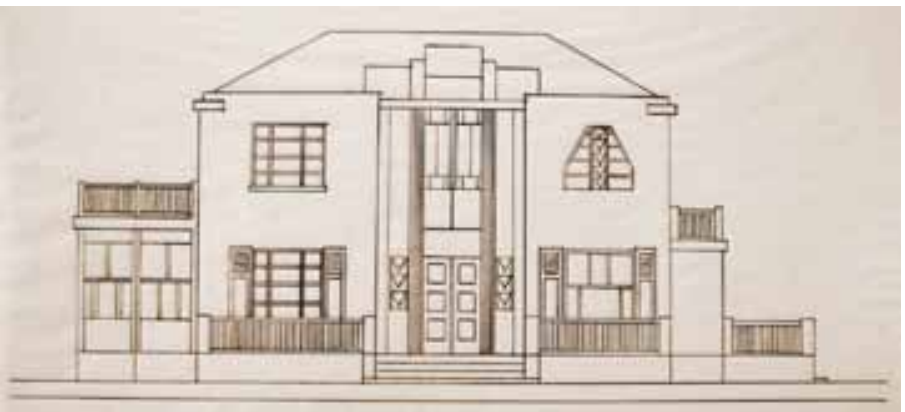

Fig. 3. Design of façade. Mansion at Kalna prospekts 3, Ogre. 1927. Teodors Hermanovskis. [8]

in the front door glazing and triangular bay structures, which were probably introduced in modern architecture thanks to Peter Behrens' New Way paradigmatic building, the first modernist house (1926) [1].

The essence of Hermanovskis' creative temperament is best demonstrated by the design of the building at Kalna Prospekts (Avenue) in Ogre. The plans of building façades show that Art Deco style is manifested in particularly exaggerated decorativeness: the main façade graphically vibrates with four different configurations of windows, with changing window setup (from 6 to 12 panes) and shape, from rectangular to trapezoidal (Figure 3). Unfortunately, the design was not implemented in full; subsequent reconstructions resulted in some of the architect's

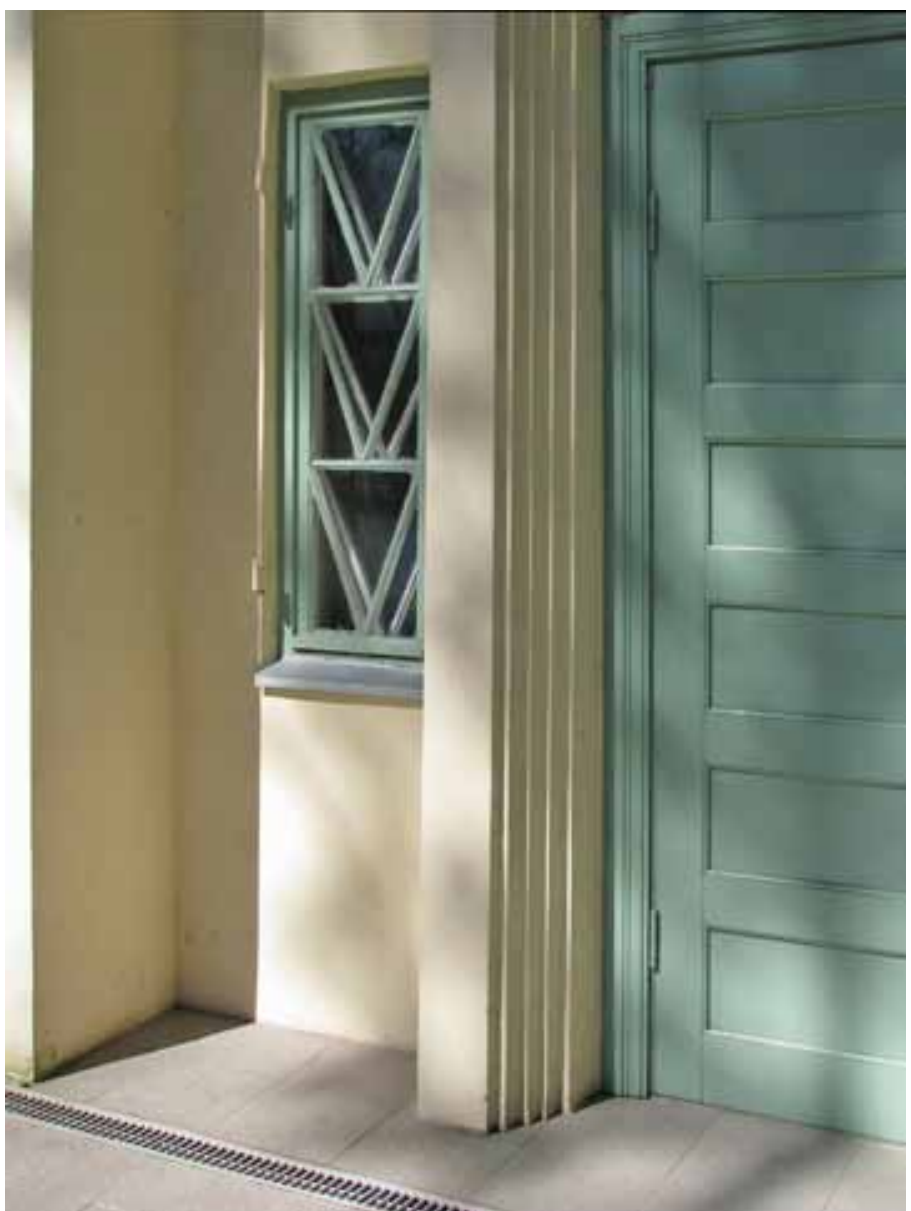

Fig. 4. Façade fragment. Mansion at Kalna prospekts 3, Ogre. 1927. Teodors Hermanovskis. [7]

ideas being lost, including the trapezoidal window in the garden façade, whereas the porch with the terrace was transformed into a two-storey extension. As a testimony to the architect's attitude towards windows as an essential component of a building, we see the window frames of the antechamber with the original zigzag strutting (Figure 4).

Yet, the building reveals masterful composition of construction shapes and alignment of decorative components the façades are enriched with multiplicative composition of planes, creating expressive effects of light and shadow play. They magnificently adorn dynamic plane breakdown of the main façade and the numerous individual components: the ziggurat-shaped gable outline and the composition of its planes, dominating over the relatively flat roof, the profiling of the pilasters surrounding the entrance, the bay and the dynamics of its planes. At Kalna Prospekts 3, Hermanovskis created one of the most magnificent samples of mansions in Latvia, where the aesthetics of Art Deco in the 1920s - Style 1925 - is fully reflected. Hermanovskis also incorporates the decorative motifs of the 1920s into Art Deco aesthetics in the shapewise fairly traditional two-storey plastered wooden summer cottage at Kalna Prospekts 8 (1925): a zigzag motif in the balcony railing and an outspokenly Cubist step-shaped capital for the supports (Figure 5).

Buildings displaying typical functionalism, or Modern Movement, which, due to the plastic construction shapes and 


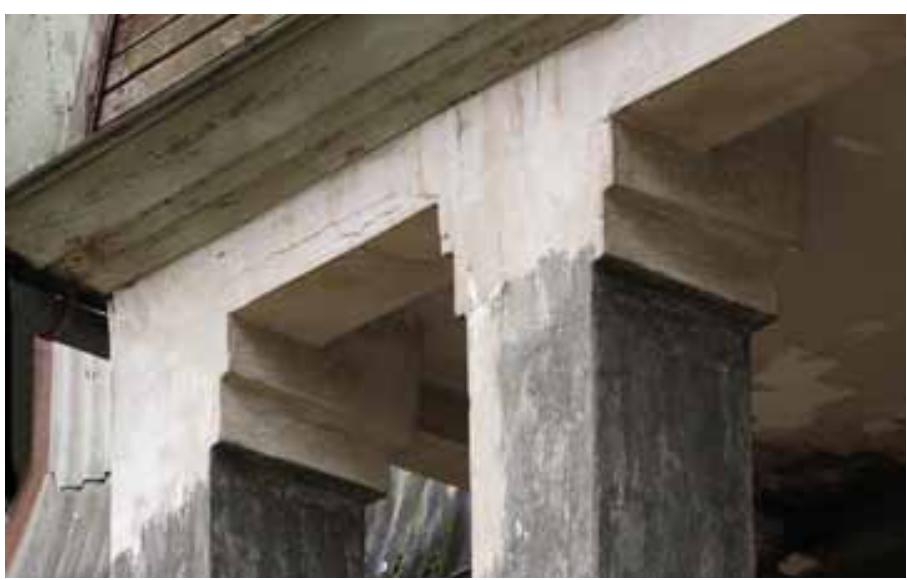

Fig. 5. Façade fragment. Mansion at Kalna prospekts 8, Ogre. 1925. Teodors Hermanovskis. [7]

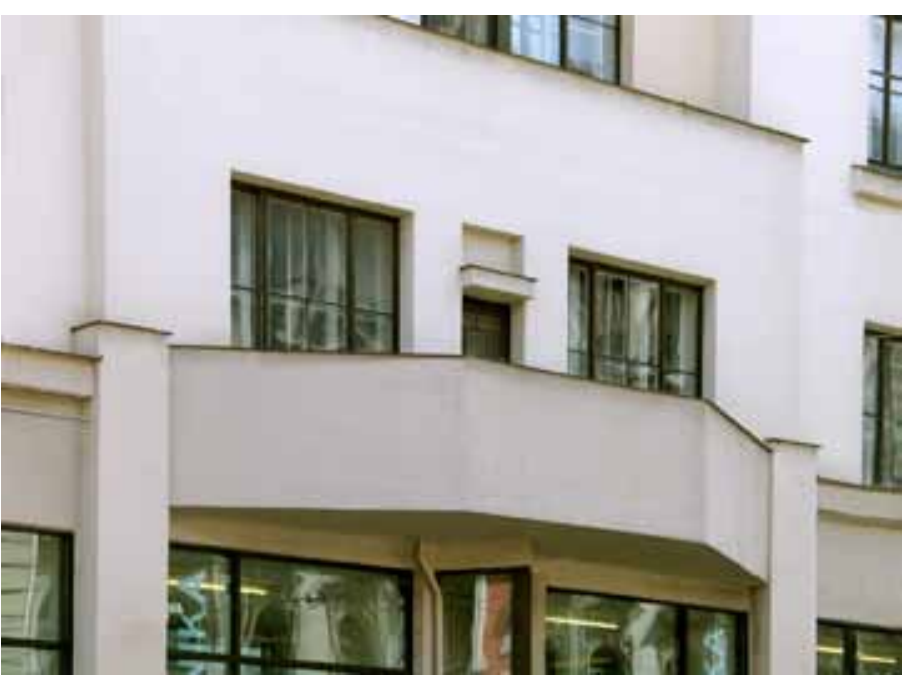

Fig. 6. Polygonal balcony, apartment and business house, Marijas iela (street) 8 , Riga. 1926. Teodors Hermanovskis. [7]

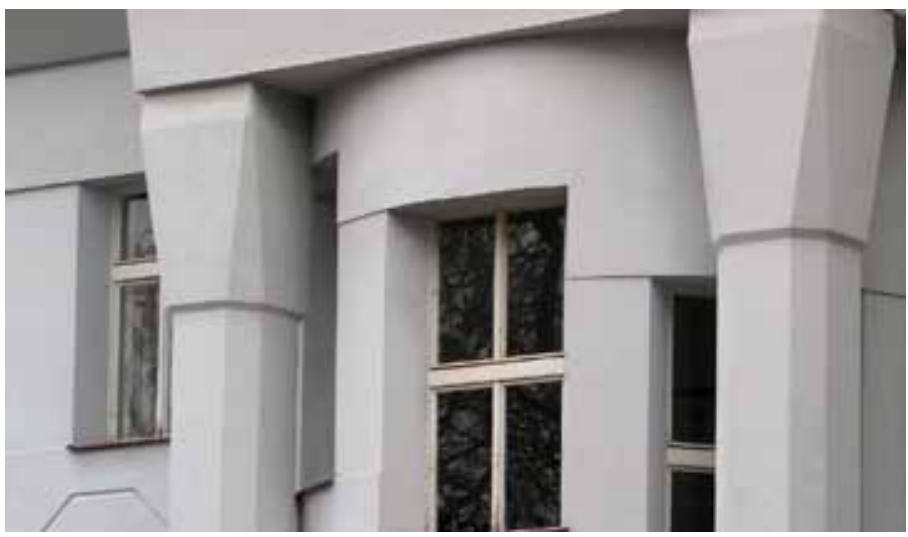

Fig. 7. Portal fragment, Hofmann Mansion (Hoffmannova vila) at Tychonova ulica (street) 4, Prague. 1912-1913. Josef Gočár. [7]

certain form solutions, possess the decorativeness of Art Deco aesthetics and are not common in Hermanovskis' creative legacy. It is not surprising that in the late 1920s and during the 1930s in Europe "Art Deco architecture, gradually accustoming the audience, increasingly begins to use the experiences of functionalism" [2].
Teodors Hermanovskis' residential/utility building at Marijas iela 8 (1926) is considered to be the first such example in Latvia. The five-storey house is attractive thanks to its laconic façade solution, where the emphasis is placed on the ground floor and the first floor with a polygonal balcony. The edges of the balcony, maintaining the rhythm proportions of the façade composition, are implemented in cubic shapes, which unwittingly recalls the Czech cubist method of breaking classic shapes, yet without the angular accent that is characteristic of Czech Cubism (Figure 6 and 7). Further impressive elements of the façade are niches and cornices, and a dynamic triangular bay structure, harmoniously breaking the plane of the façade. Three years later, Hermanovskis used similar shapes in the rental house at Bruninieku iela 45 (1929), where the composition was similar: 11a triangular bay structure and a polygonal balcony dominated in the centre, combining in the façade the aesthetics of Functionalism, Zig-Zag Moderne, the ziggurat theme in the building pediment and classical aesthetics.

Discussions on how to view individual cases of rather rational architecture in the 1920s and 1930s allowed the architectural historian Rosemarie Haag Bletter to point out in the 1970s that, due to insufficient studies of Art Deco, it was not clear how the creative work of Le Corbusier, Walter Gropius and Mies van der Rohe could be associated with Art Deco, and to criticize the tendency to associate all interwar architecture with the Art Deco style [3]. On the other hand, the Russian scholar Tatyana Malinina (Татьяна Глебовна Малинина) stated that it was necessary to choose an overall criterion to deal with the problems related to the coexistence of Art Deco and International style [4]. Apublication of Brooklyn University professor Marcia Reiss offers a compromise: using the term Art Moderne for the coexistence of Functionalism, Art Deco Streamline and the decorative elements of Art Deco [5]. It is believed that the modern composition of construction shapes first appeared in the "Tomorrow's House" by the U.S. designer and architect Norman Bel Geddes. Terraces, ramps and streamlines, as well as "(...) provocative geometric curves all demonstrate how much American Deco owed to the avant-garde architecture of Russian Constructivists such as Iakov Chernikov and Konstantin Melnikov", [1, 20] although these features appeared in Europe already in the villa of the fashion designer Paul Poiret by Robert Mallet-Stevens (1924-1925, Mézy-sur-Seine, France).

Teodors Hermanovskis implemented a number of dynamic from the point of view of Art Moderne - compositions of cubic shapes in his works, juxtaposing horizontal and vertical shapes. $\mathrm{He}$ arranged construction shapes dexterously, enriching them with terraces, balconies, porthole-type windows and streamline, departing from symmetry and conventional solutions. Examples that are more known in architectural history are the houses in the "quiet" areas of Riga, such as the smart semi-detached house at Ojāra Vācieša iela 13 (1931), the mansions at Ojāra Vācieša iela 33 (1927), Mazā Nometnuu iela 6 (1927), Bergenas iela 8 (1928), all built by Hermanovskis' design. There, Functionalism lost its balanced "peace" and obtained a strong form and plastics of façades, demonstrating the principles of Art Moderne. Hermanovskis' talent to display world-class architectural mastery even in small projects is demonstrated by the building in Riga at Ojāra Vācieša iela 33 


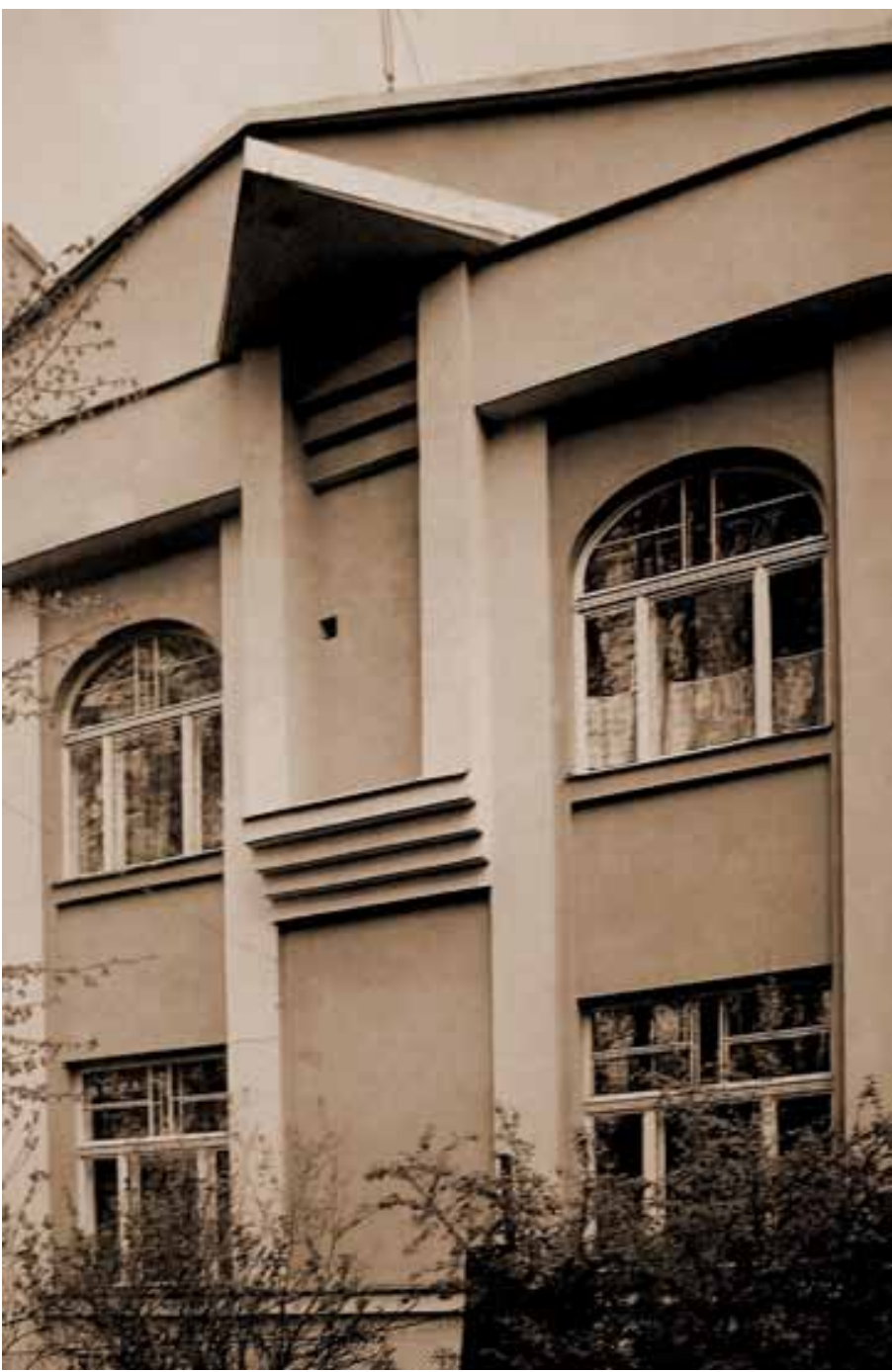

Fig. 8. Façade fragment, 33 Ojāra Vācieša iela, Riga. 1927. Teodors Hermanovskis. [10]

(1927), where the principle of the architectural image of façade is essentially the same as in the impressive sample of Tropical Deco in Miami, Florida (Figures 8, 9).

Another splendid example can be found in Ogre: the house designed at Brīvības iela 48 (1934) for the pharmacist Ieva Kere, the daughter of apothecary Pēteris Širons. The changes of the postwar years have not altered the main idea, namely, the presence of Art Deco aesthetics in Art Nouveau interpretation: a dynamic composition of cubical volumes, several terraces, supplemented by streamline attributes characteristic of the thirties - the streamline motif in the terrace and the porthole-type windows (Figure 10).

Ogre projects of the 1930s show that the shape modulation, cultivated for many years by Hermanovskis, reached a clear and perfect vertical/ horizontal proportion: the building at Strēlnieku iela 2 (1935?), built on the commission of public servant Alīda Strautmane, illustrates this concept with simplicity, harmony and elegance.

Here, the expression principle of the shapes is practically the same as in the building atBrīvības iela 48 (1934); however, the verticality of shape is more pronounced, especially in the view from the street (Figure 11).

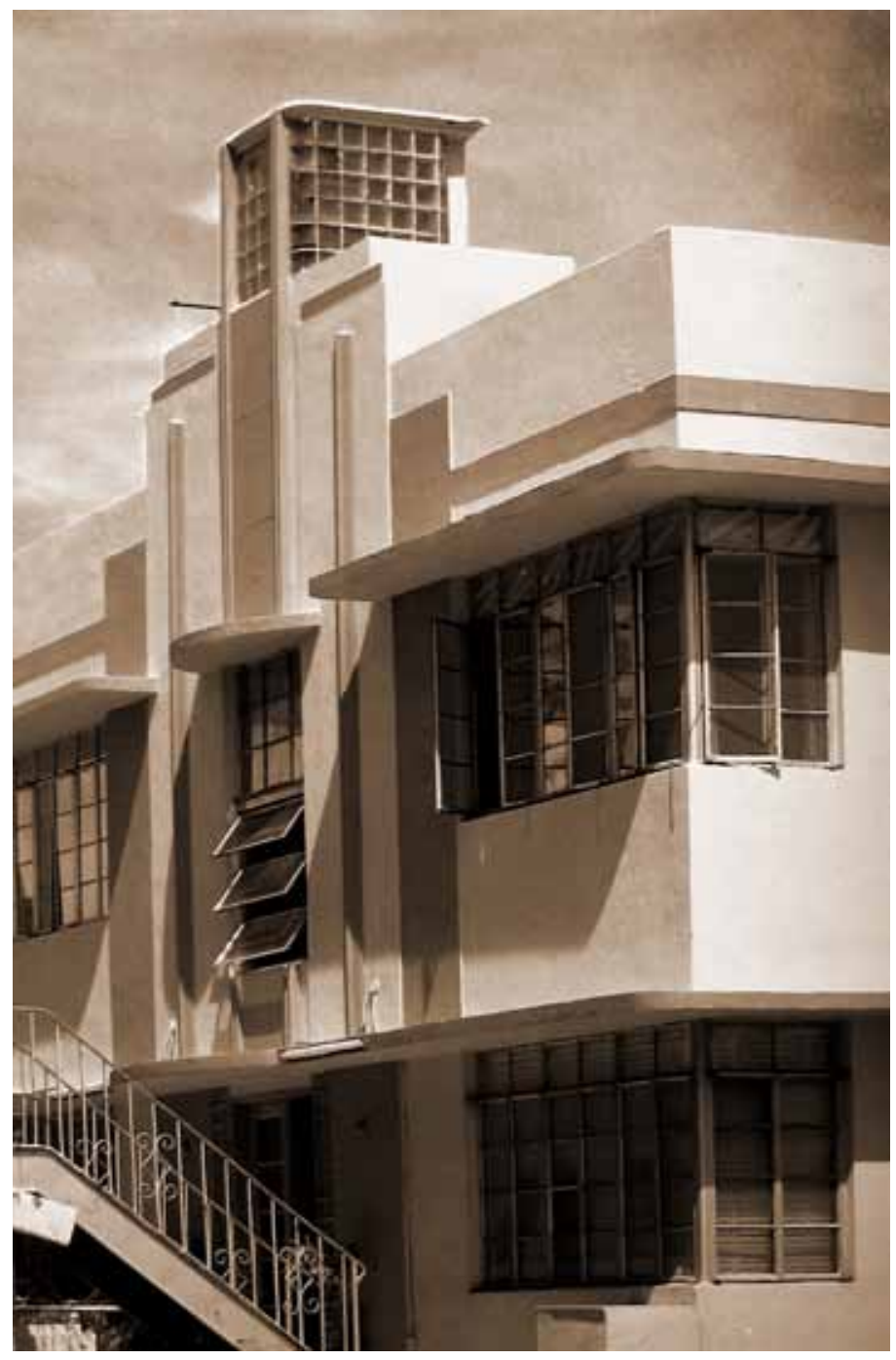

Fig. 9. Mansion façade in Tropical Deco style, Miami, Florida, USA. 1930s. [9]

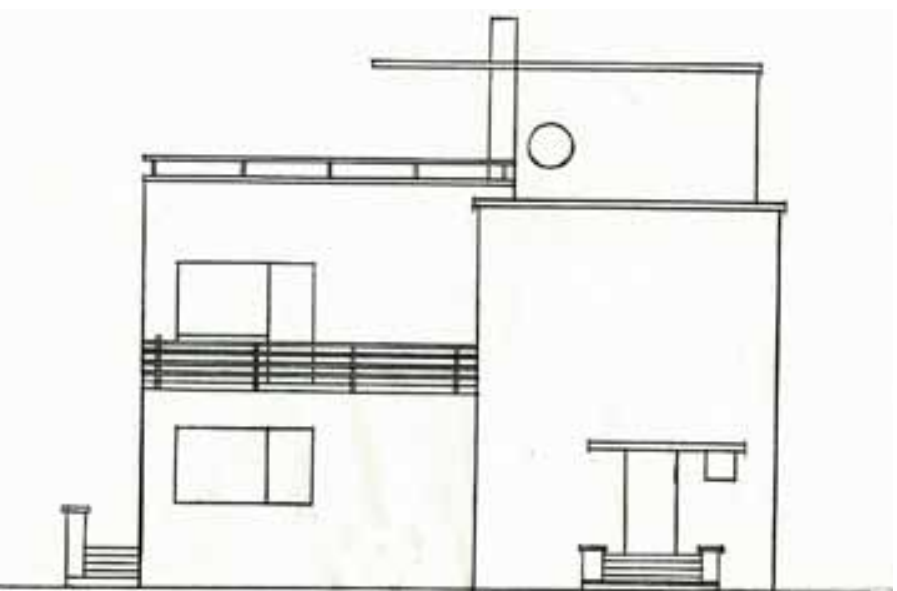

Fig. 10. Design of garden façade. Mansion at Brīvības iela 48, Ogre. 1934. Teodors Hermanovskis. [11]

Again, the architect incorporated circular windows in the wall plastics, yet, unlike the project of Brīvības iela, at Strēlnieku iela he also rounded the door box, which, together with the rhythm of the building volumes, made a neat connection to the liner theme of the thirties. The building at Strēlnieku iela 


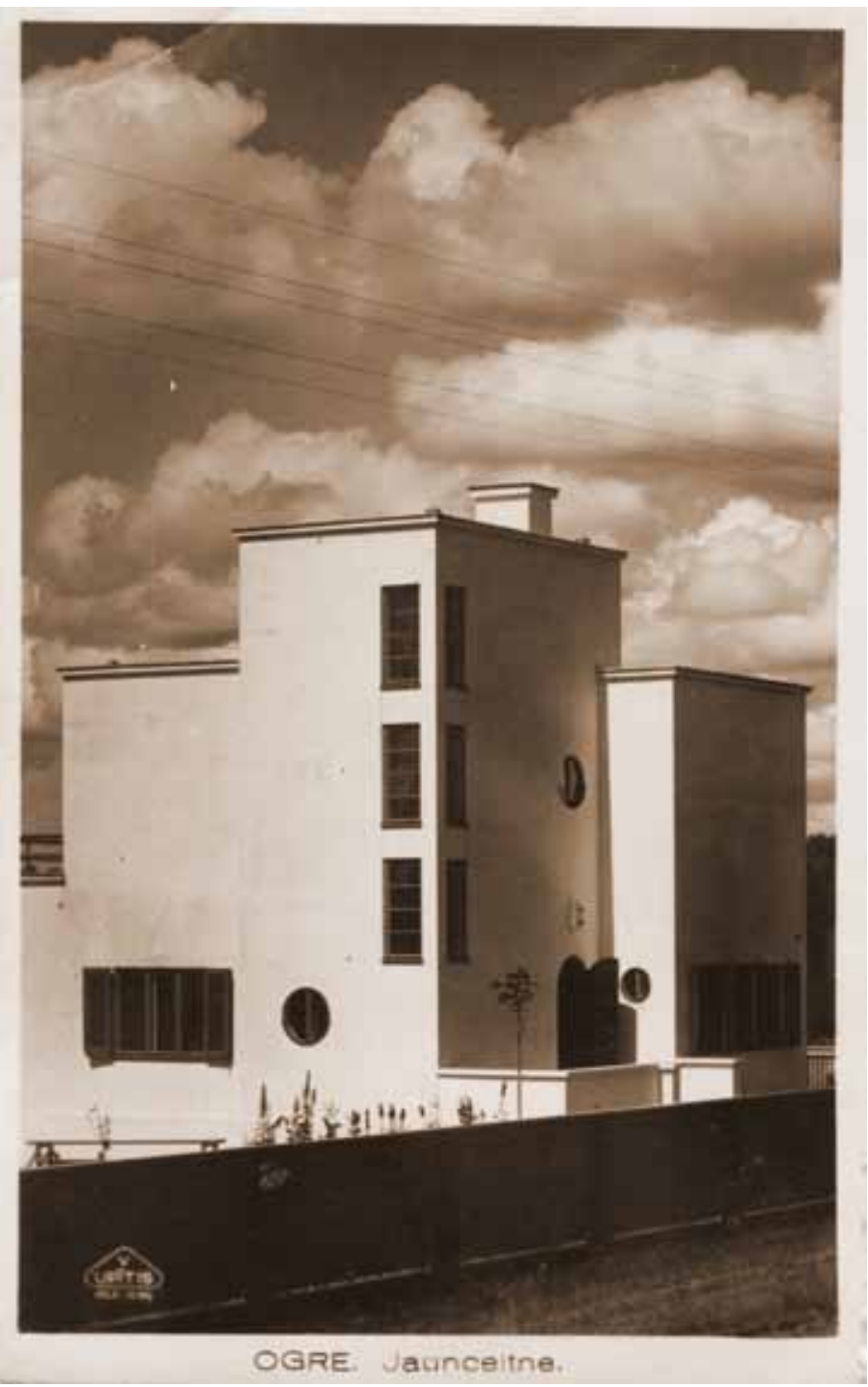

Fig. 11. Mansion at Strēlnieku iela 2, Ogre. 1935(?). Teodors Hermanovskis. [12]

is one of the rare cases where separate interior elements of the thirties and their paint treatment have remained untouched, for example, the two-leaved door in the living-room with the round brass door handle of the type popular in Europe (Figures 12, 13, 14), the original dark cerise tone on the living-room door and in the staircase, as intended by Hermanovskis (Figures 15, 16, 17). Even after seventy-five years, the intensity of the tone has not faded.

Post-war reconstructions resulted in the loss of the original sun-lounge with exit to the garden, which was separated from the living-room by a glass wall with built-in glass shelves with chromium-plated edging (Figure 18). The use of chromiumplated metals, which were fashionable in Europe at that time, was also approved by reviewers in Latvia. Already in 1929, the art historian Visvaldis Pengerots wrote about the progressive evolution of constructivist building and design, or the development of the interior decorator, as manifested, for example, in the use of metals, which "revolutionizes the statics of furniture, establishes new rhythms, where the world outlook of the $20^{\text {th }}$ century is fully reflected." [6] Photographs from Alīda Strautmane's family archive with views of the house and its interior are the examples

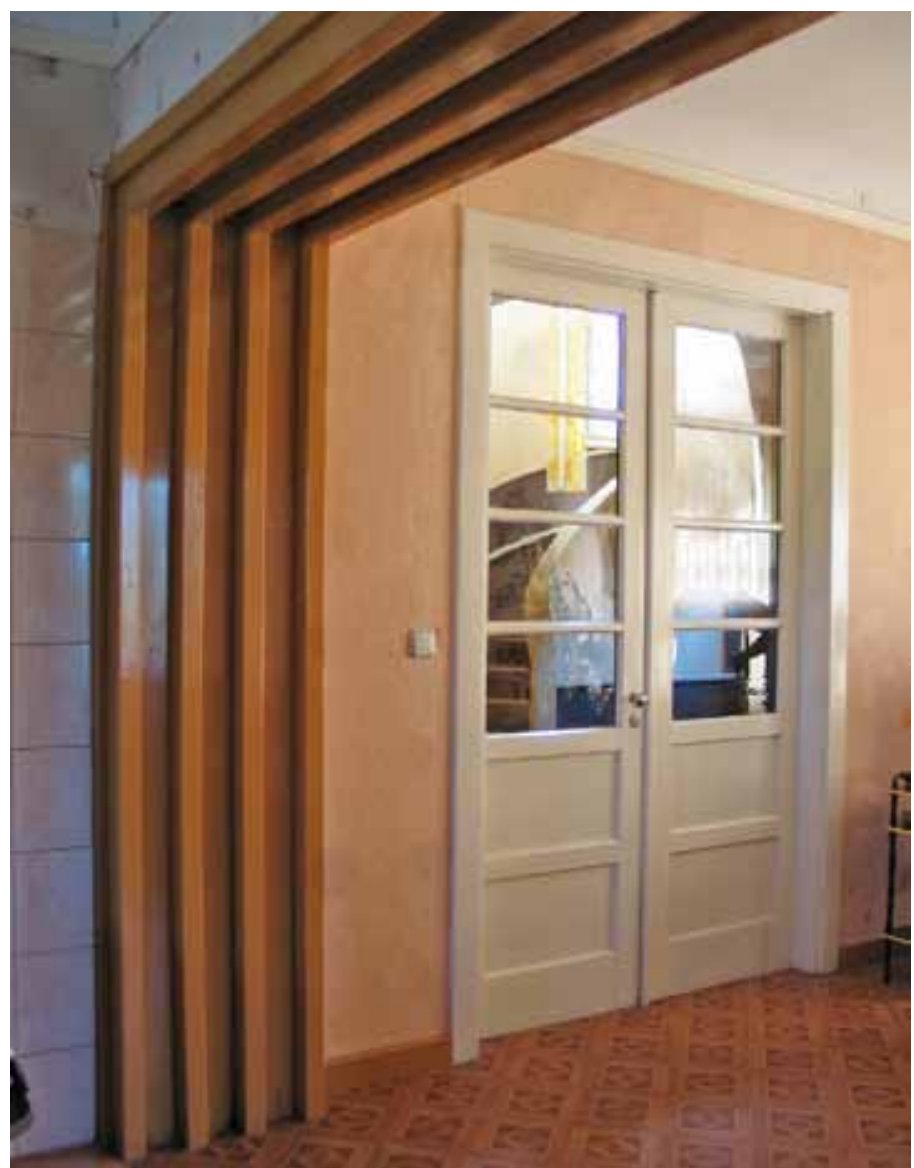

Fig. 12. Living-room. Mansion at Strēlnieku iela 2, Ogre. 1935(?). Teodors Hermanovskis. [7]

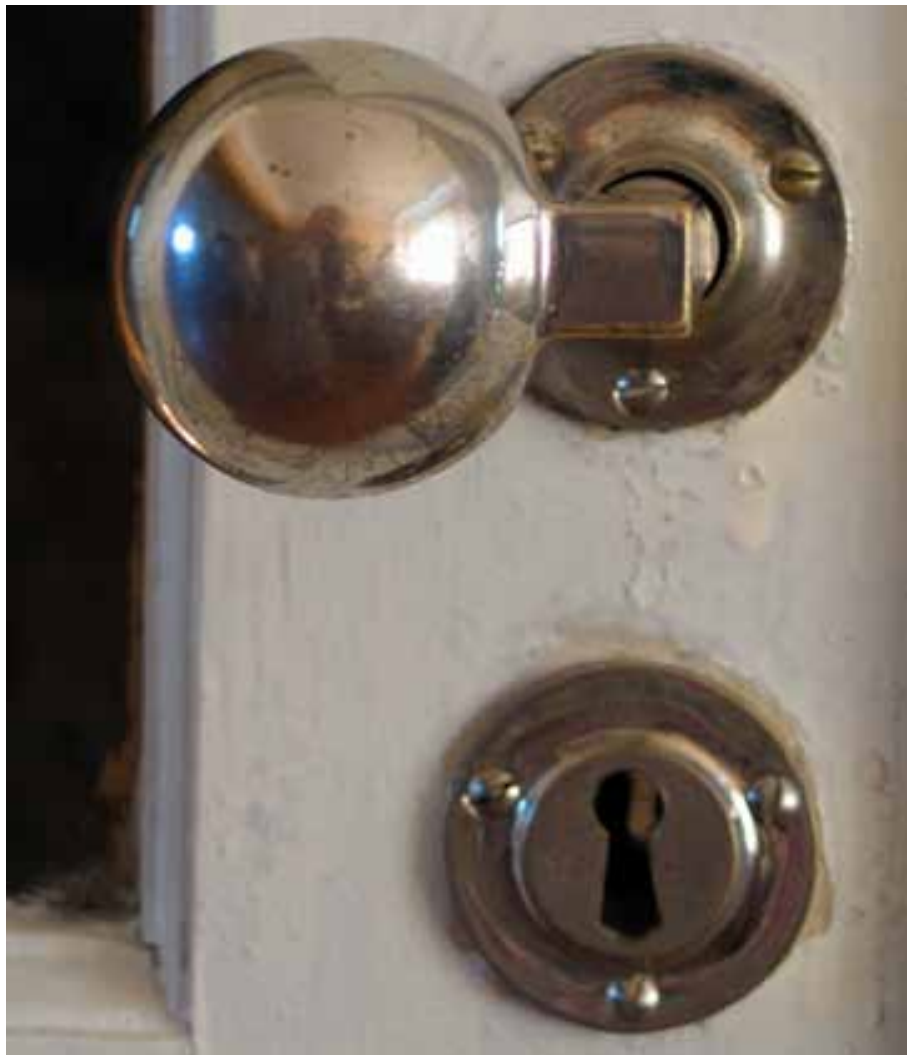

Fig. 13. Round brass door handle, living-room. Mansion at Strēlnieku iela 2, Ogre. 1935(?).Teodors Hermanovskis. [7] 


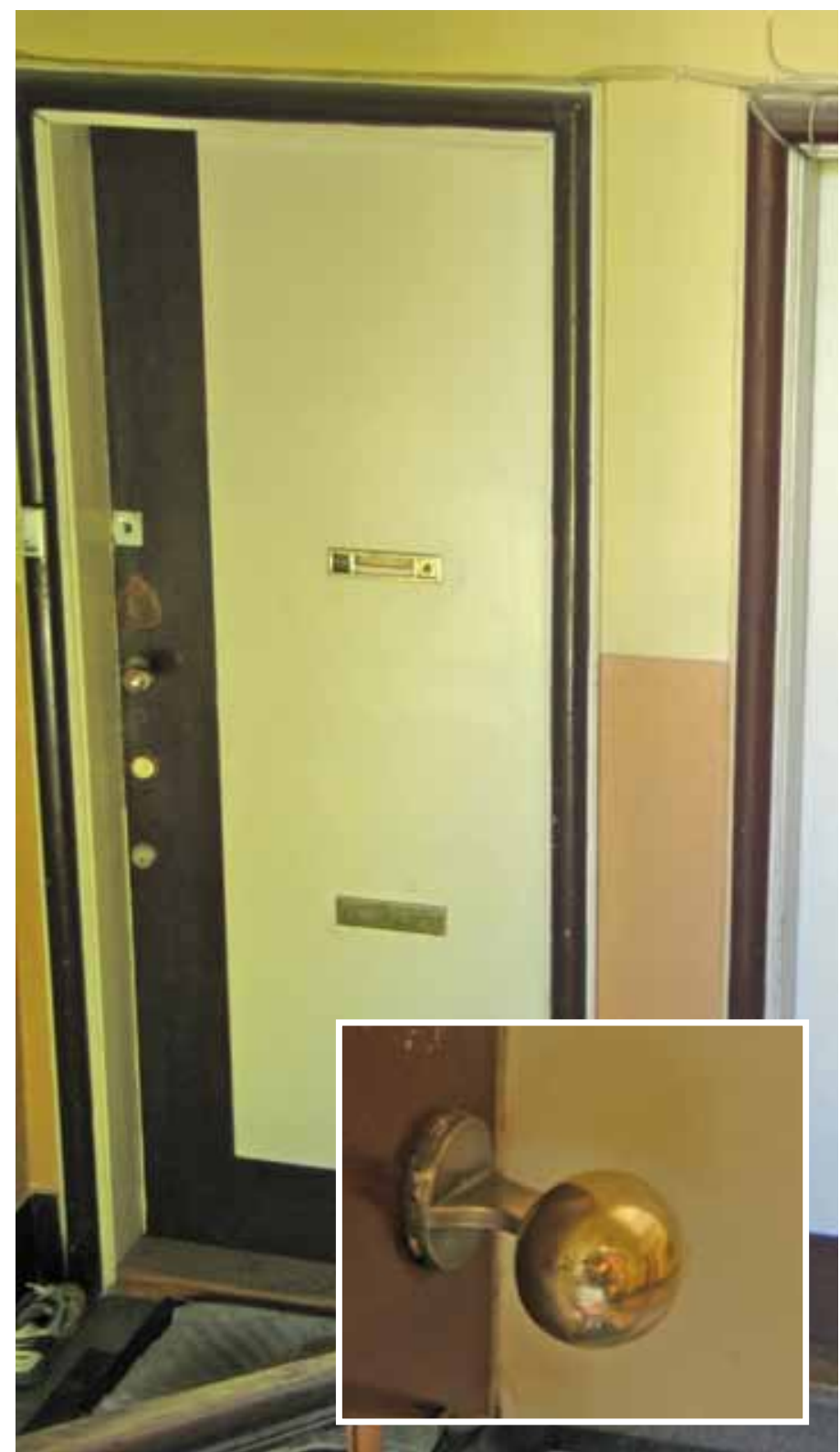

Fig. 14. Apartment houses door and Round brass door handle at ulica Krovoderska 65a, Kraków. 1936. Arch. Zygmunt Grunberg. [7]

of Hermanovskis' ability to persuade his clients to use modern materials and forms in the projects. Hermanovskis' creations were strongly formed by the rational element, prevailing over the decorative tendency, which was implemented in harmony with architectural volume. His ability to expressively arrange basic geometrical shapes, preserving balance and not giving up dynamics and expression, matches the world's best achievements. At the same time, his works do not succumb entirely to the principles of the Modern Movement. Following principles of Bauhaus, which were the symbol of radical innovations of the $20^{\text {th }}$ century, Hermanovskis promoted implementation of the modern building type in Latvian architecture, the followers of which were also after the World War II. Teodors Hermanovskis can be considered a master of mansions, an implementer of innovate and daring ideas in interwar Latvia, where his projects have had an important role in the sphere of research dedicated to national Art Deco style and aesthetics.

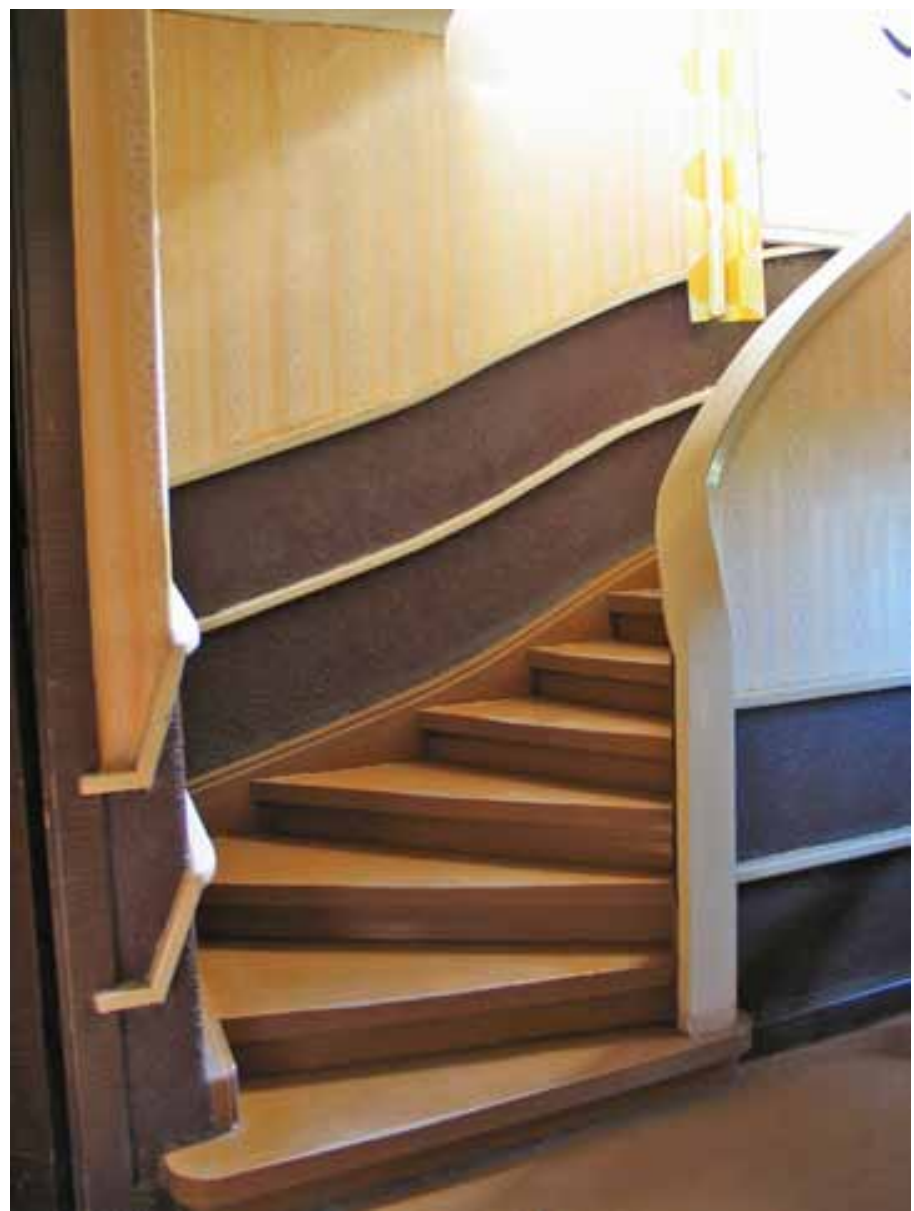

Fig. 15. Original colour scheme of living-room doors. Mansion at Strēlnieku iela 2, Ogre. 1935(?). Teodors Hermanovskis. [7].

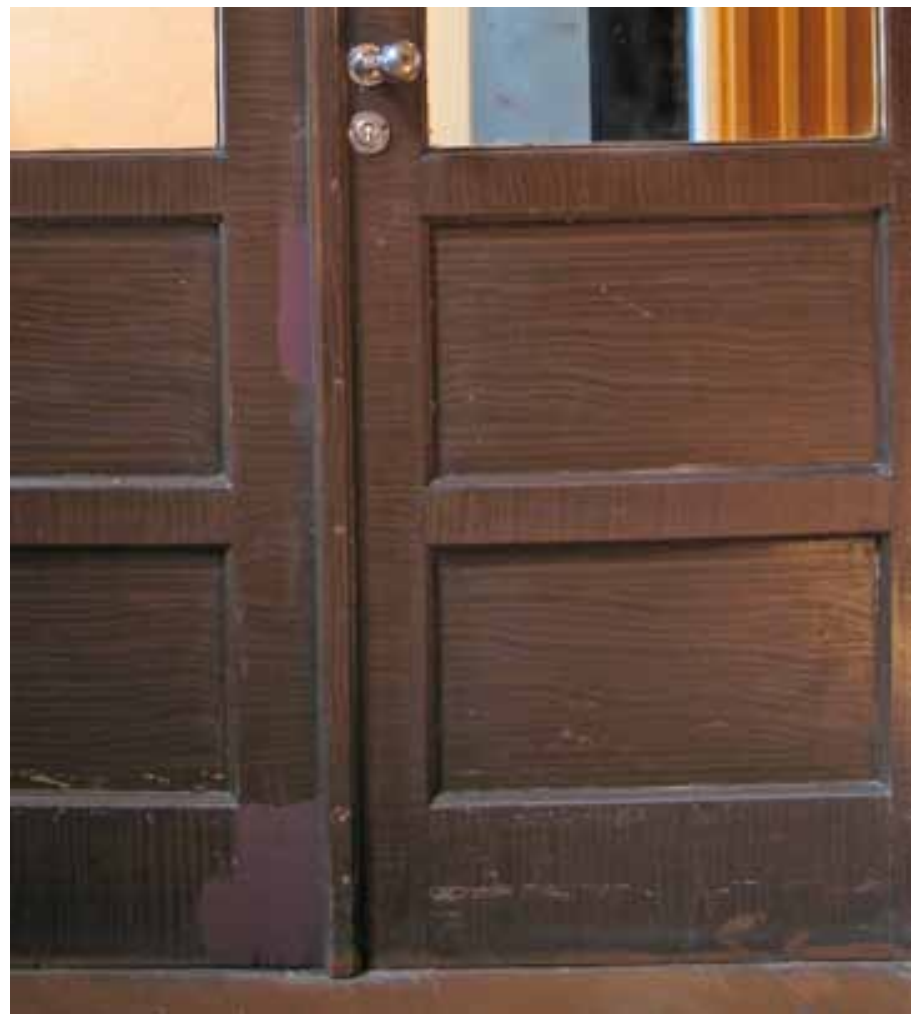

Fig. 16. Staircase, mansion at Strēlnieku iela 2, Ogre. 1935(?). Teodors Hermanovskis. [7]. 


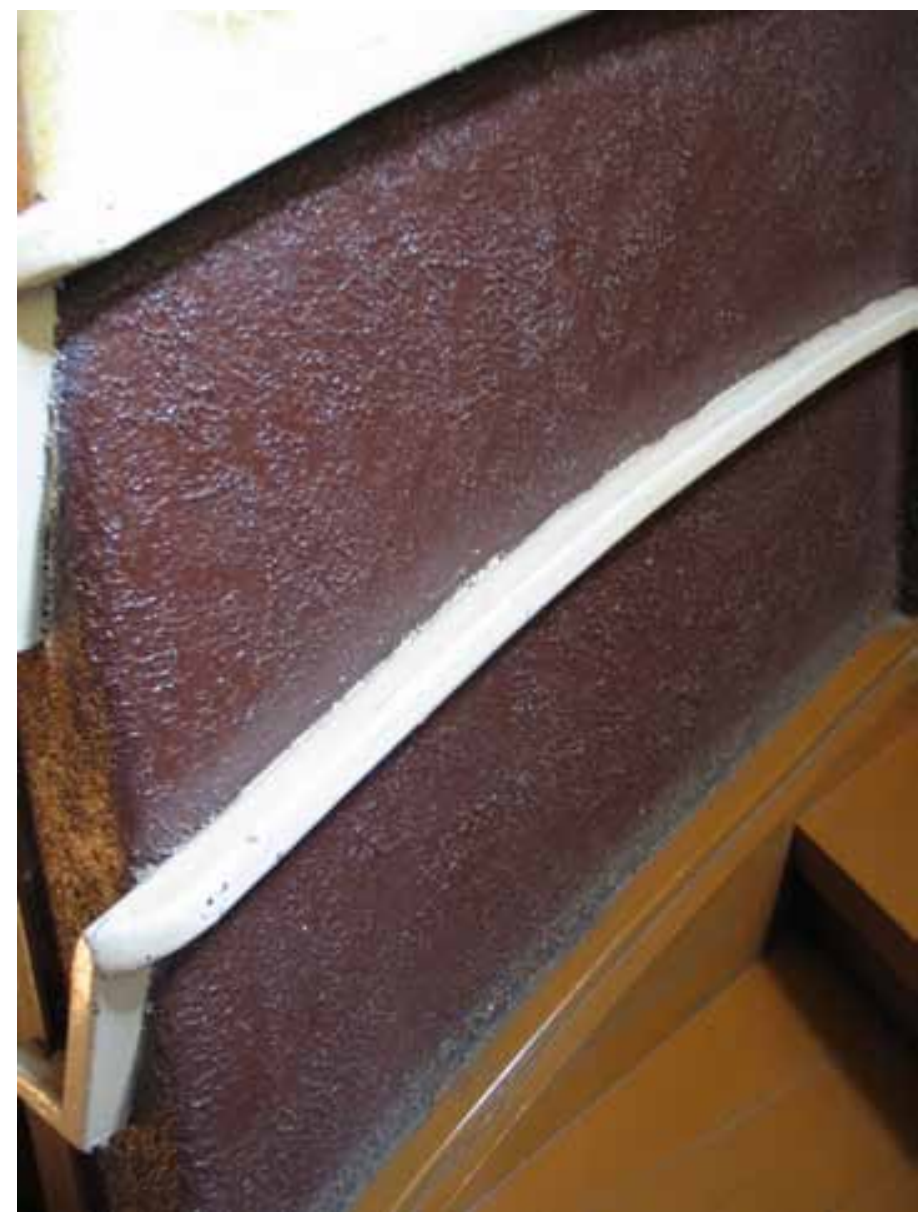

Fig. 17. Fragment of staircase wall. Mansion at Strēlnieku iela 2, Ogre. 1935(?). Teodors Hermanovskis. [7].

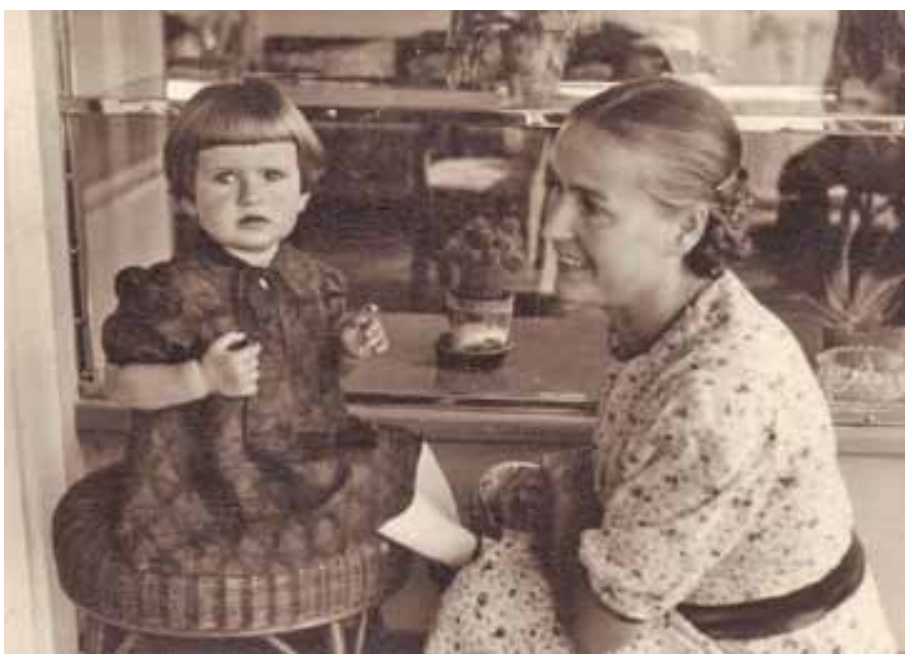

Fig. 18. Fragment of interior with a glass wall and chromium-plated shelves. Mansion at Strēlnieku iela 2, Ogre. 1935(?). Teodors Hermanovskis. [13]

\section{REFERENCES}

1. Tinniswood, A. The Art Deco House. Avant-Garde Houses of the 1920s and 1930s. London: Mitchell Beazley, 2002. p. 90-91.

2. Tołoczko, Z. i T. W kręgu architektury Art Déco. Kraków: Wydawnictwo Oddziału PAN, 1997. S. 20.

3. Robinson, C., Bletter, R. H. Skyscraper Style: Art Deco New York. New York: Oxford University Press, 1975. p. 41.

4. Малинина, Т. K вопросу об изучении феномена Ар Деко. Исскуствознание, 1999, № 1, с. 385.

5. Reiss, M. Architectural Details. London: Greenwich Editions, 2004. p. 57.

6. Penǵgerots, V. Dažas domas par konstruktīvismu. Daugava, 1929, Nr. 7, 891. 1pp.

7. Photo by Renāte Čaupale, 2006, 2008, 2010.

8. Latvian State Historical Archives, Fund 2874, Description 1, Vol. 960, Sheet 67 (Ogre Museum of History and Arts)

9. Weber, E. American Art Deco. North Dighton: JG Press, 2004. p. 28.

10. Lejnieks, J. Rīgas arhitektūra (Photographs by I. Stūrmanis). Rīga: Avots, 1989. 216. lpp.

11. Latvian State Historical Archives, Fund 2064, Description 1., Vol. 11, (Ogre Museum of History and Arts).

12. Ogre Museum of History and Arts. File "Ogre, Strēlnieku iela 2".

13. Family archive of Alīda Strautmane.

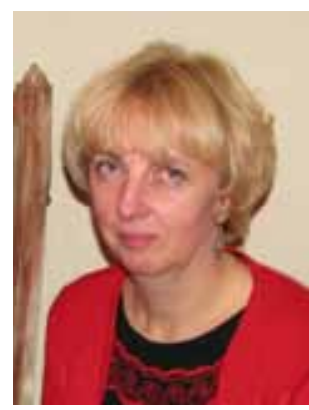

\section{Contact Data}

Renāte Čaupale

Riga Technical University, Faculty of Architecture and Urban Planning Address: Āzenes iela 16, Riga, LV-1048, Latvia

Phone: +371 26176433

E-mail: renate.caupale@apollo.lv 
Renāte Čaupale. Teodors Hermanovskis, Art Deco un mazpilsēta Ogre

Starpkaru laika Latvijā savrupmāju arhitektūra ienēma nozīmīgu vietu modernu tendenču popularizēšanā. Viens no izcilākajiem meistariem šajā jomā bija būvinženieris Teodors Hermanovskis. Šai laikā Pierīgas mazpilsēta Ogre bija ieguvusi popularitāti Rīgas inteliǵences vidū kā atpūtas un vasarnīcu vieta. Te arhitektiem bija jauna vide izaicinājumam samērā īsā laikā savrupmāju un vasarnīcu projektos realizēt modernas idejas. Tas bija laiks, kad Eiropā aktuālais funkcionālisms pielāva arī Art Deco dekorativitāti, un tā klātbūtne projektos bija organiski log̣iska. Nozīmīgākais Art Deco stila paraugs Ogrē ir Teodora Hermanovska projektētā savrupmāja Kalna prospektā 3. Tai pat laikā diskutablie viedokḷi par Art Deco veicina zināmu viedokḷu plurālismu atsevišku objektu atributējumā. Tādos projektos, kur modernās kustības (Modern Movement) jeb funkcionālisma principi koeksistē ar Art Deco dekoratīviem elementiem un Art Deco Streamline, ēku atribūtiku var sasaistīt ar vienu no Art Deco stila tendencēm - Art Moderne. Arī atseviški Teodora Hermanovska projektētās savrupmājas Ogrē būtu apskatāmas saistībā ar Art Moderne. Arhitekta projekti un liecības par interjeriem Ogrē parāda Teodoru Hermanovski kā modernu un drosmīgu ideju realizētāju starpkaru gadu Latvijāan, un meistara projekti ieṇem nozīmīgu vietu Latvijas Art Deco stila pētniecības lokā.

\section{Renāte Čaupale. Teodors Hermanovskis, Art déco und die Kleinstadt Ogre}

Architektur der Einfamilienhäuser (Villen) nahm einen bedeutenden Platz bei der Verbreitung modernen Richtungen (Tendenzen) in der Zeitperiode zwischen zwei Weltkriegen in Lettland ein. Einer der hervorragendsten Meister auf diesem Gebiet war Bauingenieur Teodors Hermanovskis. In diesem Zeitraum hatte die Kleinstadt Ogre (Vorortshaft von Riga) als Erholungs- und Sommerhausort eine große Popularität unter Intelligenz gewonnen. Die Architekten hatten hier ein neues Milieu für die Herausforderung in einer verhältnismäßig kurzer Zeit moderne Ideen in Projekten der Einfamilienhäuser und Sommerhäuser zu verwirklichen. Das war gerade die Zeitperiode, als der in Europa aktuell gewordene Funktionalismus auch den dekorativen Art-déco-Stil zuließ und seine Anwesenheit in den Projekten war logisch und naturgemäß. Das bedeutendste Muster des Art-déco-Stil in Ogre ist das von Teodors Hermanovskis projektierte Einfamilienhaus Kalnu-Prospekt 3. In derselben Zeit fördern diese diskutierbaren Standpunkte über Art déco gewissermaßen einen Pluralismus beim Attribuieren einzelner Objekte. In solchen Projekten, wo die Modern Movement oder Prinzipien des Funktionalismus nebeneinander mit den dekorativen Elementen von Art déco und Art Deco Streamline bestehen, kann man das Attribuieren der Gebäude mit einer der Stiltrichtungen von Art déco - mit Art Moderne verbinden. Auch einzelne von Teodors Hermanovskis projektierten Einfamilienhäuser in Ogre wären in Verbindung mit Art Moderne zu behandeln. Projekte und Aussagen des Architekten über Innenausstatungen in Ogre zeigen ihn als einen Vollzieher von hochmodernen und kühnen Ideen in Lettland der Zwischenkriegsjahre und die Projekte des Meisters nehmen einen wichtigen Platz in der Erforschung des Art-déco-Stil in Lettland ein

Ренате Чаупале, Теодор Хермановский. Арт-деко и пригород Огре

В период в между первой и второй мировыми войнами (1918-1939) архитектура особняков в Латвии занимала значимое место в популяризации современных тенденций. Одним из выдающихся мастеров подобных тенденций был инженер Теодор Хермановский (Teodors Hermanovskis). Пригород Огре в этот период приобрел популярность среди интиллегенции как дачный и курортный городок. Для архитекоров этот район являлся новой средой стимулом для создания модных проектов в довольно короткий срок. Это было время, когда в Европе актуальный функционализм включал и себя и декоративность Арт-деко. И это явление стало органичным. Самым ярким примером стиля Арm- деко стал особняк, построенный по проекту Теодора Хермановского по адресу проспект Кална, 3 в Огре. Дискуссии, проводящиеся в наше время по поводу стиля Аpm-деко, отличаются плюрализмом взглядов на атрибуты объектов. В таких объектах, где принципы функционализма или Modern Movement соседствуют с декоративностью Apm-деко и Art Deco Streamline, атрибуты обьектов можно отнести к одной из тенденций Apm-деко - Art Moderne. Некоторые из проектов Теодора Хермановского в Огре также относятся к стилю Art Moderne. Проекты и сведения об интерьерах Теодора Хермановского свидетельствуют о его мастерстве и профессионализме как современного и смелого архитектора, работы которого занимают значимое место в исследовании стиля Арт-деко в Латвии.

Acknowledgements: Ogre Museum of History and Arts, chief specialist Evija Smiltniece, Irēna Dimitrijeva and Valdis Dimitrijevs. 


\title{
Teodors Hermanovskis, Art Deco un mazpilsēta Ogre
}

\author{
Renāte Čaupale, R̄̄gas Tehniskā universitāte
}

ATSLĒGAS VĀRDI: arhitektūras vēsture, Art Deco savrupmāja, funkcionālisma savrupmāja, 1920. un 1930. gadi.

Divdesmitā gadsimta divdesmitajos - trīsdesmitajos gados jaunās valsts Latvijas arhitektūrā bija saskatāmas noteiktas, tam laikam Eiropai raksturīgas, aktivitātes. Nozīmīgu lomu, neskatoties uz atseviškiem oponentu izteikumiem presē, spēlēja modernās kustības (Modern Movement) jeb funkcionālisma idejas, kas savas saknes bija radušas Deutsche Werkbund un Bauhausa skolā, piedāvājot Eiropai piln̄̄gi jaunu arhitektonisko domāšanu - virzību uz vienkāršu ǵeometrisku formu arhitektūru.

Modernajām vēsmām bija atvērtas ne tikai lielās Latvijas pilsētas - politiskajās un ekonomiskajās pārmainās tika ierautas arī mazpilsētas un rosību sākušie daudzie kultūras centri. Ogre, neskatoties uz to, ka tik tikko - 1928. gadā - bija ieguvusi savu pilsētas statusu, aktīvi veidojās kā Pierīgas kultūras un atpūtas pilsētina. Kā būtisks faktors ciešai saiknei ar galvaspilsētu bija regulāra vilcienu satiksme. Nelielo un kluso pilsētu pie Ogres upes kā savu atpūtas vietu bija izvēlējušies daudzi Rīgas inteliğences pārstāvji. Šeit arhitektiem bija jauna vide izaicinājumam samērā īsā laikā, reizēm ar diezgan pieticīgu materiālu klāstu un finansiālu ieguldījumu, savrupmāju un vasarnīcu projektos realizēt pasaulē aktuālās modernās idejas. Tas bija laiks, kad funkcionālisms pieḷāva arī Art Deco klātbūtni, un tā klātbūtne projektos bija organiski log̣iska.

Starpkaru gados svarīga loma Latvijas arhitektūras izaugsmē bija Teodoram Hermanovskim, būvinženierim pēc izglītības. Būdams izcils modernās kustības jeb funkcionālisma meistars Rīgas daudzdzīvoklu namu un sabiedrisko celtnu arhitektūrā, vin̄̌ radīja arī daudzas savrupmājas, kas vēl šodien bagātina ne tikai ,provinciālo” Pārdaugavas un citu Rīgas privātmāju rajonu bagātīgi apzalımotās mazstāvu apbūves kultūrvidi, bet arī Ogri. Toreizējā Pierīgas kūrortā Hermanovskis uzcēla ne vienu vien villu, kuru projekti nebūt neatpalika, bet reizēm pat pārspēja paša arhitekta dinamiskajiem būvformu salikumiem galvaspilsētā. Starp tiem kā drosmīgākais Art Deco projekts ir Hermanovska projektētais savrupnams Ogrē, Kalna prospektā 3 (1. attēls).

Pilsētas pievārtes priežu ielenkumā, gleznainā pakalnā tika uzcelta savrupmāja Annas Ozolinas un Rīgas bankas pārvaldnieka Paula Ozolina ğimenei. Māja uzrunā ar dinamisku un kontrasttonos risinātu fasādi. Tieši šeit, jau 1927. gada projektā, līdzịgi kā Rīgā Mazajā Nometņu ielā 6 (1927), un vēl agrāk - Marijas ielā 8 (1926), apsteidzot kanonisko piemēru Parīzē - īres un veikalu namu „Le Normandy” (1929, arh. Jean Desbouis), T. Hermanovskis realizēja trīsstūra škērsgriezuma erkeri ar logiem, kas fasādes kompozīcijā ir galvenais un izteikti dinamisks akcents (2. attēls).

Trīsstūra konfigurācijas formas elementi kā Art Deco arhitektūras dekoratīvais elements spilgtākā vai mērenākā izpildījumā sastopami visā Eiropā. Tā 1928. gada Architectural Review plašajā pārskatā par jaunāko Anglijas arhitektūru tika publicētas tolaik celto raksturīgāko māju fotogrāfijas un plāni, starp kuriem bija arhitekta Tomasa Teita (Thomas S. Tait) projektētās rindu mājas dārzu ciematā Silver End Eseksā. Teita projektētajām mājām tradicionāli bija lēzeni jumti, un Eseksā tie bija krāsoti smaragdzali, papildinot ar šo krāsu arī atseviškas fasādes detalas, tā izraisot toreizējā angḷ sabiedrībā samērā noraidošu vērtējumu. Ēkas, būdamas izteikti vienkāršas un zināmā mērā vērtētās kā garlaicīgas, tika atdzīvinātas tikai ar dažām detaḷām - tieši Art Deco detaḷām - ǵeometriskiem motīviem parādes durvju stiklos un stiklotiem trīsstūra škēersgriezuma erkeriem, kurus modernajā arhitektūrā, iespējams, ieviesa, pateicoties Pētera Bērensa (Peter Behrens) New Way paraugceltniecībai [1].

Hermanovska rodošā temperamenta būtību demonstrē tieši Ogres ēkas projekts Kalna prospektā. Ēkas fasāžu plāni parāda, ka šeit Art Deco stils izpaužas īpaši pārspīlētā dekorativitātē: galvenā fasāde grafiski vibrē ar četriem dažādas konfigurācijas logiem, kur mainās logu spraišlojums (no 6 līdz 12 rūtīm) un forma - no taisnstūra līdz trapecei (3. attēls). Diemžēel projekts netika realizēts pilnībā, bet turpmāko pārbūvju rezultātā atseviškas arhitekta ieceres ir zudušas, to skaitā trapecveida logs dārza fasādē, bet veranda ar terasi gadu gaitā pārtapusi par divstāvu piebūvi. Kā liecība arhitekta attieksmei pret logu kā nozīmīgu celtnes sastāvdalu ir saglabājušies priekštelpas logu rāmji ar oriǵinālo zig-zag spraišlojumu (4. attēls).

Tomēr līdz šodienai ēka atklāj būvformu un dekoratīvo detaḷu kārtojuma meistarību - fasādes bagātinātas ar multiplikatīvu plakṇu kārtojumu, radot izteiksmīgu gaismēnu rotaḷu efektus. Tie krāšni uzrunā galvenās fasādes dinamiskajā plakṇu dalījumā un daudzajās atseviškajās detaḷās: zikurāta formas frontona konturējumā un tā plakṇu kārtojumā, dominējot pār samērā lēzeno jumtu, ieejas ieskaujošo pilastru profilējumā, erkera un tā plakṇu dinamikā. Kalna prospektā 3 Hermanovskis radījis vienu no krāšnākajiem savrupmāju paraugiem Latvijā, kurā visā piln̄̄bā izpaužas Art Deco divdesmito gadu Stila 1925 estētika.

Hermanovskis iekḷauj divdesmito gadu dekoratīvos motīvus Art Deco estētikā arī visnotal tradicionālajā pēc formām divstāvu apmestas koka vasarnīcā Kalna prospektā 8 (1925) - zig-zag motīvu balkona margās un spēcīgu kubisku formu pakāpjveida kapiteli balstu vainagojumā (5. attēls).

Modern Movement jeb funkcionālisma ēkas, kurām, pateicoties būvformu plastikai un atseviškiem formu risinājumiem, piemīt Art Deco estētikas dekorativitāte, Hermanovska dailradē nav retums. Tas bija likumsakarīgi, jo divdesmito gadu norietā un trīsdesmitajos Eiropā,,ArtDeco arhitektūra,pakāpeniskipieradinot publiku, sāk arvien vairāk izmantot funkcionālisma pieredzi" [2]. Par pirmo šādu paraugu Latvijā uzskata T. Hermanovska īres un veikala namu Marijas ielā 8 (1926). Piecstāvu nams uzrunā ar 
lakonisku fasādes risinājumu, kur akcents ir likts uz pirmo un otro stāvu ar poligonālu balkonu. Balkona škautnes, saglabājot fasādes kompozīcijas ritma proporcijas, ir kubiskās formās, kuras nevilus atgādina čehu kubistu klasisko formu laušanas pan̄ēmienu, tomēr bez čehu kubismam raksturīgā slīplenkka akcenta (6., 7. attēls). Fasādes izspēli turpina nišas un dzegas, un dinamisks trīsstūra škērsgriezuma erkers ar logiem, harmoniski laužot fasādes plakni. Trīs gadus vēlāk Hermanovskis līdzīgas formas lietoja īres namam Bruņinieku ielā 45 (1929), kur kompozīcija līdzīga - centrā dominē trīsstūra škērsgriezuma erkers ar logiem un poligonāls balkons, apvienojot fasādē funkcionālisma, Zig-Zag Moderne, zikurāta tēmu ēkas frontonā un klasisko tradīciju estētiku.

Diskusijas par to, kā vērtēt atsevišķu divdesmito - trīsdesmito gadu visnotal, racionālu arhitektūru, rosināja arhitektūras vēsturnieci Rozmariju H. Bleteri (Rosemarie Haag Bletter) septindesmitajos gados atzīmēt, ka nepietiekamas Art Deco izpētes dēl nav saprotams kā Lekorbizjēe, Valtera Gropiusa un Mīss van der Roe dailurade ir saistāma ar Art Deco, un kritizēja tendenci visu starpkara arhitektūru saistīt ar Art Deco stilu [3]. Savukārt krievu zinātniece Tatjana Maḷiņina (Татьяна Глебовна Малинина) uzsvēra, ka tieši jāizvēlas kopējais kritērijs, kas vārētu risināt Art Deco un internacionālā stila koeksistences problemātiku [4]. Bruklinas universitātes profesores Marsijas Reisas (Marcia Reiss) publikācijā piedāvāts kompromiss apzīmējums Art Moderne - funkcionālisma, Art Deco streamline un Art Deco dekoratīvo elementu koeksistencei [5]. Tiek uzskatīts, ka modernais būvformu kārtojums pirmoreiz parādījās ASV dizainera un arhitekta Normana Bela Gedesa (Norman Bel Geddes) „Rītdienas mājā”. Terases, rampas un pludlīnijas, kā arī ,provokatīvas ǵeometriskas formas demonstrēja, cik daudz American Deco bija aizguvis no krievu konstruktīvistu Jakova Černihova (Яков Чернихов) un Konstantīna Mel,nikova (Константин Мельников) - avangardiskās arhitektūras" $[1,20]$, lai gan Eiropā šīs iezīmes var saskatīt jau Robēra MalēStevensa (Robert Mallet-Stevens) projektētajā modes meistara Pola Puarē villā (Villa

Poiret; 1924-1925, Mézy-sur-Seine, Francija).

Teodors Hermanovskis savā daiḷradē realizēja ne vienu vien šādu - Art Moderne skatījumā - dinamisku kubisku formu kompozīciju, pretstatot horizontālas un vertikālas formas. Arhitekts virtuozi kārtoja būvformas, bagātinot tās ar terasēm, balkoniem, iluminatora formas logiem un pludlīniju, atsakoties no simetrijas un ordināriem risinājumiem. Arhitektūras vēsturē vairāk zināmas ir pēc Hermanovska projektiem uzceltās mājas Rīgas "klusajos" rajonos, piemēram, dvīnu ēka Ojāra Vācieša ielā 13 (1931), savrupmāja Ojāra Vācieša ielā 33 (1927), M. Nometnu 6 (1927), Bergenas ielā 8 (1928). Tajās funkcionālisms zaudējis nosvērto „mieru” un ieguvis spēcīgu formu un fasāžu plastiku, uzskatāmi parādot Art Moderne principus. Hermanovska talantu - realizēt pasaules līmeña arhitektūras meistarību pat nelielos projektos - demonstrē ēka Rīgā Ojāra Vācieša ielā 33 (1927), kuras fasādes arhitektoniskā veidola princips neatškiras no iespaidīgā Tropical Deco parauga Majami, Floridā (8.,9. attēls) .

Spilgts piemērs ir arī Ogrē aptiekāra Pētera Šĩrona meitai farmaceitei Ievai Kerei 1934. gadā projektētā savrupmāja Brīvības ielā 48. Pēckara gadu vērienīgās pārmainas nav mainījušas pašu galveno - Art Deco estētikas klātbūtni Art Moderne interpretācijā: dinamisku kubisku formu kārtojumu un vairākām terasēm, papildinātus ar trīsdesmito gadu streamline atribūtiem - pludlīniju motīvu terasē un iluminatora formas logiem (10. attēls).

Trīsdesmito gadu piemērs Ogrē liecina, ka Hermanovska gadiem izkoptais formu modulējums sasniedzis skaidru un perfektu vertikālo un horizontālo proporciju samēru: ēka Strēlnieku ielā 2 (1935?), kas tika celta pēc valsts ierēdnes Alīdas Strautmanes pasūtījuma, ilustrē šo koncepciju ar vienkāršību, harmoniju un eleganci. Formu izteiksmes princips praktiski neatškiras no ēkas Brīvības ielā 48 (1934), tomēr ir izteiktāka formu vertikalitāte, īpaši skatā no ielas (11. attēls). Arī te arhitekts sienu plastikā iekḷāva apaḷos logus, bet, atškirīīā no Brīvības ielas projekta, Strēlnieku ielā noapaloja arī durvju aili, kas, kopumā ar būvapjomu ritmu, korekti saista ar trīsdesmito gadu lainera tēmu.

Strēlnieku ielas māja ir viena no retajām, kurā ir saglabājušies neskarti atseviški trīsdesmito gadu interjera elementi un to krāsojums. Piemēram: viesistabas divviru durvis ar apalas formas misina rokturi, kāds Eiropā nebija retums (12., 13., 14. attēls); oriğinālais Hermanovska iecerētais tumšais ķiršu tonis viesistabas durvīm un kontrastējošais krāsojums kāpṇu telpā (15., 16., 17. attēls), kuru toṇa intensitāte nav mainījusies pat pēc septindesmit pieciem gadiem.

Pēckara pārbūvju rezultātā zudusi savdabīga stiklota telpa veranda ar izeju uz dārzu, kuru no viesistabas atdalīja stikla siena ar iebūvētiem stikla plauktiem ar hromētām apmalēm (18. attēls). Eiropā moderno hromēta metāla lietojumu interjeros atzin̄̄gi novērtēja arī kritiki Latvijā. Vēl 1929. gadā mākslas vēsturnieks Visvaldis Pengerots rakstīja par konstruktīvisma, kā tai laikā Latvijā apzīmēja modernās kustības principu arhitektūru, celtniecības un dizaina, toreiz - telpu dekoratora, progresīvo attīstību, piemēram, metāla pielietošanā, kas ,radikāli pārmaina mēbeḷu statiku, rada jaunus ritmus, kuros visā pilnībā atspoguḷojas XX gs. s. pasaules uzskats", [6].

Alīdas Strautmanes ǵimenes fotogrāfijas ar mājas un tās interjera skatiem ir viens no piemēriem par Hermanovska spēju pārliecināt pasūtītāju par modernu materiālu izmantojumu un formu realizāciju projektos. Teodora Hermanovska daiḷadē spēcīgi izpaudās racionālais, prevalējot pār dekoratīvo, kas risināts harmonijā ar arhitektonisko apjomu. Viṇa spējas izteiksmīgi kārtot ǵeometriskās pamatformas, saglabājot līdzsvaru, neatsakoties no dinamikas un ekspresijas, atbilst labākiem pasaules sasniegumiem. Tai pat laikā viņa darbos nav absolutizēti Modern Movement principi. Sekojot Bauhausa principiem, kas 20. gadsimtā bija arī radikālu jauninājumu simbols, Hermanovskis veicināja Latvijas arhitektūrā moderna ēku tipa ieviešanu, kuram sekotāji bija arī pēc II pasaules kara. Teodoru Hermanovski var uzskatīt par savrupmāju meistaru, jaunu un drosmīgu ideju realizētāju starpkaru gadu Latvijā, kur Meistara projekti ienem nozīmīgu vietu Latvijas Art Deco stila un estētikas pētniecības lokā.

Pateicība Ogres Vēstures un mākslas muzejam, īpaši galvenajai speciālistei Evijai Smiltniecei, kā arī Irēnai un Valdim Dimitrijeviem. 


\section{ATtĒLI}

1. att. Savrupmāja Kalna prospekts 3, Ogre. 1927. Teodors Hermanovskis. [7] 2. att. Fasādes fragments, savrupmāja Kalna prospekts 3, Ogre. 1927. Teodors Hermanovskis. [7]

3. att. Fasādes projekts, savrupmāja Kalna prospekts 3, Ogre. 1927. Teodors Hermanovskis. [8]

4. att. Fasādes fragments, savrupmāja Kalna prospekts 3, Ogre. 1927. Teodors Hermanovskis. [7]

5. att. Balstu vainagojums, vasarnīca, Kalna prospekts 8, Ogre. 1925. Teodors Hermanovskis. [7]

6. att. Poligonālais balkons, īres un veikala nams, Marijas iela 8, Rīga. 1926. Teodors Hermanovskis. [7]

7. att. Portāla fragments, Hofmana savrupmāja (Hoffmannova vila), Tychonova ul. 4, Prāga. 1912-1913. Josef Gočár. [7]

8. att. Fasādes fragments, Ojāra Vācieša iela 33, Rīga. 1927. Teodors Hermanovskis. [10]

9. att. Savrupmājas fasāde Tropical Deco stilā, Maijami, Florida, ASV. XX gs trīsdesmitie gadi. [9]

10. att. Dārza fasādes projekts, savrupmāja Brīvības iela 48, Ogre. 1934. Teodors Hermanovskis. [11]

11. att. Savrupmāja Strēlnieku iela 2, Ogre. 1935(?).Teodors Hermanovskis. [12] 12. att. Viesistabas fragments, savrupmāja Strēlnieku ielā 2, Ogre. 1935 (?). Būvinž. Teodors Hermanovskis. [7]

13. att. Viesistabas durvju rokturis, savrupmāja Strēlnieku ielā 2, Ogre. 1935 (?). Būvinž. Teodors Hermanovskis. [7]

14. att. Dzīvokḷa durvis un durvju rokturis, dzīvokḷu nams, ulica Krovoderska 65a, Krakova. 1936. Arh. Zygmunt Grunberg. [7]

15. att. Viesistabas durvju oriǵinālais krāsojums, savrupmāja Strēlnieku iela 2 Ogre. 1935(?). Teodors Hermanovskis. [7]

16. att. Kāpnu telpas kontrastainais sienas krāsojums, savrupmāja Strēlnieku ielā 2, Ogre. 1935 (?). Būvinž. Teodors Hermanovskis. [7]

17. att. Kāpṇu telpas sienas fragments, savrupmāja Strēlnieku ielā 2, Ogre. 1935

(?). Būvinž. Teodors Hermanovskis. [7]

18. att. Interjera fragments ar stikla sienu un plauktiem ar hromējumu. Savrupmāja Strēlnieku iela 2, Ogre. 1935(?). Teodors Hermanovskis. [13]

\section{IZMANTOTIE AVOTI}

1. Tinniswood, A. The Art Deco house. Avant-Garde Houses of the 1920s and 1930s. London: Mitchell Beazley, 2002. P. 90, 91.

2. Tołoczko, Z. i T. W kręgu architektury Art Déco. Kraków: Wydawnictwo Oddziału PAN, 1997. S. 20.

3. Robinson, C., Bletter, R. H. Skyscraper style: Art Deco New York. New York: Oxford University Press, 1975. P. 41.

4. Малинина, Т. K вопросу об изучении феномена Ар Деко. Исскуствознание, 1999, № 1, с. 385.

5. Reiss, M. Architectural details. London: Greenwich Editions, 2004. P. 57.

6. Peṇǵerots, V. Dažas domas par konstruktīvismu. Daugava, 1929, Nr. 7, 891. 1pp.

7. Renātes Čaupales fotofiksācija, 2006, 2008, 2010.

8. Latvijas Valsts vēstures arhīvs, 2874 f., 1. apr., 960. lieta, 67. lapa, (Ogres vēstures un mākslas muzejs).

9. Weber, E. American Art Deco. North Dighton: JG Press, 2004. P. 28

10. Lejnieks, J. R̄̄gas arhitektūra (I. Stūrmaṇa fotogrāfijas). Rīga: Avots, 1989. 216. 1pp.

11. Latvijas Valsts vēstures arhīvs, 2064. f., 1. apr., 11. lieta, (Ogres vēstures un mākslas muzejs)

12. Ogres vēstures un mākslas muzejs. Lieta: "Ogre, Strēlnieku iela 2".

13. Alīdas Strautmanes ğimenes arhīvs. 